DOI: https://doi.org/10.18524/2519-2523.2021.16.245735

УДК 94(477):322:821.161.2-6Мазепа

\title{
THE EPISTOLAR LEGACY OF HETMAN IVAN MAZEPA AS A SOURCE FOR THE STUDY OF THE RELATIONSHIP BETWEEN THE AUTHORITIES AND THE ORTHODOX CLERGY
}

\section{Ivan Lupol}

Post-graduate student

of the Department of History of Ukraine

Odesa I. I. Mechnikov National University

2, Dvoryanska Str., Odesa, 65082, Ukraine

ORCID: http: //orcid.org/ 00000001-9860-4109

E-mail: ivan.ser.lupol@gmail.com

Citation: Lupol, I. (2021) The epistolar legacy of Hetman Ivan Mazepa as a source for the study of the relationship between the authorities and the Orthodox clergy. Chornomors' $k a$ mynuvshyna, vol. 16, pp. 10-15.

Submitted: 18.11 .2021

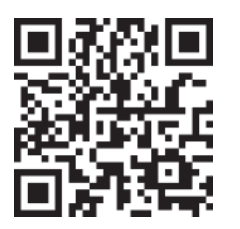

\section{Annotation}

The purposes of this article are to highlight on the basis of the epistolary legacy of Hetman Ivan Mazepa his relationship with the Ukrainian Orthodox clergy, the main directions, ways and methods of helping the Ukrainian Orthodox Church, to follow determine certain directions of Hetman I. Mazepa's activity in relation to the Orthodox Church in the Ukrainian lands, on the basis of his epistolary heritage, which was aimed at comprehensive assistance to the church; to establish the main directions of his help and the ways in which Hetman helped the Ukrainian Orthodox clergy.

The article analyzes a certain part of the epistolary heritage of Hetman I. Mazepa. The set of letters used in the study makes it possible to trace the main trends in the relations of Hetman I. Mazepa with the Ukrainian Orthodox Church during his reign.

It was found that most of the studied and analyzed letters of Hetman I. Mazepa to various representatives of the Orthodox clergy and some representatives of the Cossack officers speak of comprehensive support of the Orthodox Church in Ukrainian lands (benefits, material assistance, protection of Ukrainian Orthodox clergy at the political level, etc. e.). The letters also clearly show the tendency that Hetman I. Mazepa tried to make the Orthodox Church one of his main pillars for consolidating his power (it is clearly traced in the letters dated to the first years of his reign).

Key words: Hetman Ivan Mazepa, Cossack sergeant, Ukrainian Orthodox Church, church hierarchs, clergy, monasteries.

\section{ЕПІСТОЛЯРНА СПАДЩИНА ГЕТЬМАНА ІВАНА МАЗЕПИ ЯК ДЖЕРЕЛО ДО ВИВЧЕННЯ ВЗАСМИН ВЛАДИ З ПРАВОСЛАВНИМ ДУХОВЕНСТВОМ}

\section{Іван Лупол}

Аспірант кафедри історії України Одеський національний університет імені I. I. Мечникова Вул. Дворянська, 2, м. Одеса, 65082, Україна

ORCID: http: //orcid.org/ 00000001-9860-4109

E-mail: ivan.ser.lupol@gmail.com

\section{Анотація}

Мета поданої статті полягає в тому, щзоб на основі епістолярної спадщини гетьмана Івана Мазепи висвітлити його взаємини з украӥнським православним духовенством, простежити основні напрями, шляхи та методи допомоги Православній церкві та духовенству.

У статті проаналізовано певну частину епістолярної спадщини гетьмана I. Мазепи. Використаний в 
Цитування: Лупол I. Епістолярна спадщина гетьмана Івана Мазепи як джерело до вивчення взаємин влади з православним духовенством. Чорноморська минувшина: записки Відділу історії козацтва на півдні України : зб. наук. пр. / за. ред. В. А. Смолія. Одеса: ФОП Бондаренко М.О., 2021. Вип. 16. C. $10-15$.

Отримано: 18.11.2021 p. прочесі дослідження комплекс листів дає можливість прослідкувати головні тендениії, напрями та методи в його взаєминах з Православною иерквою на територіі Гетьманщини. Виявлено, щзо в більшості вивчених та проаналізованих листів гетьмана I. Мазепи православному духовенству та окремим представникам козацькой старшини йдеться про різнобічну підтримку Православної иеркви на украӥнських землях, зокрема: надання пільг, матеріальної допомоги, захист інтересів представників українського православного духовенства на політичному рівні тощо. У листах чітко простежується тенденція I. Мазепи зробити Православну церкву своїм союзником і опорою гетьманської влади.

Ключові слова: гетьман Іван Мазепа, козацька старшина, Православна церква, церковні ієрархи, духовенство, монастирі.

Вивчення історії православної церкви в Україні є досить актуальним на тлі сучасної трансформації українського православ'я. Українське козацтво завжди виступало в ролі захисника та покровителя Православної церкви на сучасних українських землях. Ця політика стала особливо виразною та чіткою після Берестейської унії, коли Православна церква втратила свою легітимність та поступово почала втрачати свій вплив, а іiі духовенство опинилось під загрозою зникнення з багатьох причин, а саме: відсутність централізованої підтримки від державної влади, перехід багатьох представників православної церковної еліти до греко-католицької церкви під зверхність Папи Римського, поступове переміщення центру православного життя Східної Європи з Києва до Москви. Підтвердженням даних фактів $є$ діяльність гетьмана П. Сагайдачного, націлена на відродження православної ієрархії. Подальші козацькі гетьмани зробили свій внесок у розвиток Православної церкви на території України. Серед них особливо виділяється постать гетьмана Івана Мазепи, який доклав чимало зусиль до процесу піднесення та укріплення Київської митрополії, зміцнення економічного становища ії загалом та зміцнення її окремих церков та монастирів.

Питанням дослідження епохи правління гетьмана Івана Мазепи займалось багато українських істориків, зокрема: Б. Крупницький, Т. Мацьків, О. Оглоблін, С. Павленко, В. Станіславський, Т. Чухліб та інші. Вони детально висвітлили епоху правління гетьмана Івана Мазепи, дослідили різні аспекти його діяльності на основі введених до наукового обігу нових архівних документів, листів, універсалів тощо. Зокрема, Теодор Мацьків увів до наукового обігу значну кількість нових документів епохи гетьманування I. Мазепи [11]. О. Оглоблін, у своїй монографії “Гетьман Іван Мазепа та його доба", розглянув різні аспекти життя великого гетьмана. Він опублікував деякі раніше невідомі факти з біографії І. Мазепи, в тому числі й про його взаємини з представниками православного духовенства на українських землях [12]. Дослідник Б. Крупницький в своїй праці “Гетьман Мазепа та його доба" на тлі загальної діяльності І. Мазепи детально розглянув його меценатську діяльність стосовно церков та монастирів [1]. Вагомий внесок у дослідження доби Івана Мазепи зробив С. Павленко, який в своїй монографії “Іван Мазепа" навів декілька невідомих до цього фактів із життя та діяльності гетьмана [13]. Але на даний період часу бракує праць, де б грунтовно розглядалася зазначена проблема, що робить публікацію актуальною.

Meта поданої статті полягає в тому, щоб на основі епістолярної спадщини гетьмана Івана Мазепи висвітлити його взаємини 3 українським православним духовенством, основні напрями, шляхи та методи допомоги Православній церкві.

Православну церкву козацькі гетьмани розглядали як важливу опору та легітимізацію своєї влади, саме тому українська козацька еліта, і особливо гетьмани, надавали їй всіляку політичну та матеріальну допомогу. Оскільки в ті часи головним багатством та засобом 
існування для храмів та монастирів була земля, то козацька еліта, в першу чергу гетьмани, своїми універсалами постійно закріплювала старі й роздавала нові землі, приписувала селян до монастирів, надавала різні податкові пільги та економічні привілеї (монополії, оренди тощо). Таким чином, стимулюючи економічну могутність українського православного духовенства, козацька верхівка створювала собі потужного союзника в якості Православної церкви. Православна віра в світогляді звичайних людей того часу відігравала чи не найважливішу роль в житті, й саме тому всіляка підтримка козацькою елітою Церкви закріплювала серед простого населення образ козаків як захисників українських православних земель.

Можна простежити певну спадковість традиції підтримки Церкви елітою. Козацька старшина та гетьмани продовжували в цьому відношенні політику панівної верстви населення ще за часів Русі, православних князів та шляхти литовської доби, таких як князь Острозький, що певним чином легітимізувало старшину та гетьманів як правонаступників володарів цих земель в очах звичайних людей.

Яскраве свідчення такої політики мало місце в період правління гетьманів Б. Хмельницького та І. Мазепи. Саме Б. Хмельницький добивався рівноправного становища православного населення 3 католиками в Речі Посполитій, ліквідації унії, повернення монастирів, храмів і маєтностей та права Київського православного митрополита та двох єпископів бути в складі сенату Речі Посполитої. Гетьман передав Православній церкві на підлеглій йому території колишні володіння католицької церкви, захищав володіння Православної церкви на українських землях від світської влади, зобов'язував залежних селян нести повинності на користь Київської митрополії та монастирів, надав духовенству різні права та привілеї. Цю ж стратегічну лінію в церковному питанні продовжували спадкоємці Б. Хмельницького, зокрема гетьман I. Мазепа.

Слід зазначити, що на час приходу до влади І. Мазепи становище Київської митрополії в православному світі значно змінилося. Якщо раніше вона перебувала під омофором Константинопольського (Вселенського) Патріарха, то під кінець правління гетьмана I. Самойловича вона опинилась в залежності від Московського патріархату. Вона втратила свою автономію і перетворилась на рядову єпархію Московського патріархату. Це викликало відповідну реакцію зі сторони української козацької еліти. Гетьман Іван Мазепа одним із головних напрямів своєї політики вбачав збереження автономних прав Православної церкви на українських землях і розпочав активну діяльність, націлену на відновлення Київської митрополії. Проте сепаратистські позиції частини вищого православного духовенства, яке всіляко намагалося вийти з під юрисдикції Київського митрополита, не давали можливості гетьману відновити розміри Київської митрополії. Тож він зосередив свою увагу на матеріальній допомозі Церкві, що знайшло відображення в його епістолярній спадщині.

Епістолярна спадщина гетьмана Івана Мазепи, яка стосувалась Православної церкви зачіпала багато сторін економічної діяльності церковних ієрархів, церков та монастирів. Умовно, листи гетьмана можна поділити на дві категорії, а саме: ті, в яких Іван Мазепа надавав і закріплював за Православною церквою в Україні iї права та привілеї, в спірних або конфліктних ситуаціях ставав на сторону Церкви, або використовував свій вплив, щоб сприяти зміцненню позицій українського православного духовенства. До другої категорії, яка є менш чисельною, можна віднести листи, в яких I. Мазепа приймав сторону козацтва під час розгляду його протиріч з духовенством.

У процесі дослідження було виявлено показовий приклад листа, який відноситься до другої категорії. Йдеться про лист гетьмана Івана Мазепи до ігумена Свято-Миколаївського Крупицького монастиря в Батурині. У даному листі згадується про те, що монастирський староста займається свавіллям на землях, які по праву належать по спадку одному із представників козацької місцевої старшини. Гетьман даним листом висловлює прохання, яке можна інтерпретувати як прихований наказ (враховуючи статус Івана Мазепи) ігумену сприяти тому, щоб монастирський староста залишив у спокої землі, які монастирю не належать [10, с. 196-197]. 
Перша категорія листів є більш чисельною. Це листи, в яких гетьман Мазепа закріплював привілеї представників церкви, або займав сторону українського православного духовенства в конфліктних ситуаціях. Беручи до уваги, що автором цих листів був гетьман, можна зробити висновок, що дані рекомендації сприймалися як накази людям, яким ці листи були адресовані.

Дану категорію можна розділити на декілька груп, а саме: листи, в яких гетьман Іван Мазепа в рекомендаційній формі закріплював за українським православним духовенством певні привілеї, землі та права або приймав сторону церкви в спірних ситуаціях між духовенством та козаками.

У листі до отця Михайла Лежайського, архімандрита Спаського монастиря в НовгородіСіверському, йдеться про обіцянку, яку І. Мазепа дав архімандриту, а саме - компенсувати всі збитки, які монастир поніс за часів попереднього гетьмана. Також гетьман писав про те, що він особисто не несе ніякої відповідальності за всі попередні поневіряння та утиски, які монастир зазнав за часів правління гетьмана I. Самойловича. Аналізуючи даний лист, можна зробити висновок, що Іван Мазепа таким чином намагався позитивно налаштувати православних українських ієрархів до своєї персони, переманити на свою сторону, зробити своїми вірними прихильниками, розуміючи, що Церква може бути потужним союзником у справі укріплення його влади на території Гетьманщини. Даний висновок напрошується ще й тому, що даний лист датується першим роком правління Івана Мазепи, коли відбувалось формування влади новообраного гетьмана [4, с. 123-124].

Яскравим прикладом зміцнення матеріального положення Православної церкви є лист до київського полковника Мокієвського. Там йдеться про прохання Київського митрополита Варлаама Ясинського до гетьмана, щоб усі прибутки 3 житніх торгів на території Нижнього Києва переходили під юрисдикцію митрополита, що й було зроблено гетьманом. 3 даного листа можна зробити висновок, що І. Мазепа всіляко сприяв укріпленню матеріального положення Київської митрополії, надаючи вищезгадані економічні привілеї [8, с. 156].

Збереглися декілька листів гетьмана, в яких йдеться про підтвердження та закріплення за Православною церквою на українських територіях прав на землі та всього майна, яке на цих землях знаходиться.

Зокрема, в листі ігуменові Свято-Михайлівського монастиря Сильвестру Головчичу підтверджуються за монастирем права на володіння землею та усім нерухомим майном. У цьому листі гетьман гарантує те, що світська влада, в особі гетьмана та інших представників козацької старшини, не відберуть ці землі та інше майно. Навіть у випадку війни, монастирське майно все рівно буде недоторканим [7, с. 181-182].

У листі до Київського митрополита Варлаама Ясинського Мазепа підтверджував, що за Михайлівським монастирем закріплювалися два села - Кривковщина та Данилівка. Також йдеться про підтвердження та закріплення всіх попередніх прав та привілеїв за цим монастирем [2, с. 198-199]. Дані два листа чітко демонструють головний напрям політики I. Мазепи у відношенні Православної церкви на українських землях, а саме зміцнення іiі матеріального становища.

Певна кількість листів стосується територіальних суперечок стосовно відповідного розмежування земель між монастирями з однієї сторони, та світською владою, а саме полками та містами з іншої.

Наприклад, у листі до Чернігівського архієпископа Феодосія (Углицького) йдеться про територіальні суперечки між Чернігівським жіночим монастирем та Чернігівським полком [6, c. 189]. А в листі менському сотникові Івану Курочці (Курському) чітко простежується наказ урегулювати суперечку та провести розмежування між Максаківським монастирем та менськими жителями [9, с. 127].

Можна зробити висновок $з$ двох попередніх листів, що гетьманська влада брала активну участь в урегулюванні конфліктів, пов'язаних з церковною владою, особливо в тих питаннях, які стосувались церковного майна, що лише підтверджує головну тезу даного дослідження різноманітна та всіляка підтримка Церкви, в якій гетьман та старшина бачили одну із головних опор своєї влади. 
Іншою окремою групою можна виділити листи гетьмана до Московського патріарха, оскільки в даних листах простежується інший підхід, кінцевою метою якого було зміцнення позицій Православної церкви на українських землях. Використовуючи свій політичний вплив та авторитет Іван Мазепа намагався розширити автономію та авторитет українського православного духовенства.

В епістоляріях до московського патріарха Адріана чітко простежується лобіювання інтересів Київського митрополита та підвищення авторитету Київської митрополії. Наприклад: прохання дати благословення та призначити Іосифа Краківського архієреєм при митрополиті та відправити до Москви отця Никона - печерського будівничого та ієромонаха Сафонія старшого друкаря [3, с. 185; 5, с. 184]. На основі цих двох листів можна зробити висновок, що для захисту інтересів Православної церкви та підвищення iї авторитету, гетьман Іван Мазепа займався не лише зміцненням іiі матеріального положення, а й захищав іiі інтереси на політичному рівні, виступаючи політичним покровителем, захисником перед московською владою.

Проаналізувавши епістолярну спадщину гетьмана I. Мазепи, можна дійти висновку, що стратегічна лінія його церковної політики була в принципі тією ж, що й у попередників, хоча йому доводилося діяти в умовах уже значно обмеженої автономії Гетьманщини та перетворення Київської митрополії на єпархію Московського патріархату. Листи гетьмана до православних ієрархів свідчать про права та привілеї, які він надавав Православній церкві та іiі духовенству. Лояльна церковна політика І. Мазепи сприяла зміцненню Церкви на українських землях і робила православне духовенство прихильником і опорою гетьманської влади.

\section{Джерела та література:}

1. К Крупницький Б. Гетьман Мазепа та його доба / пер. 3 нім. О. К. Струкевича. Київ, 2003. URL: https://www.e-reading.club/bookreader.php/1014572/ (дата звернення: 01.11.2021).

2. Лист гетьмана I. Мазепи до київського митрополита Варлаама Ясинського, 1699 р., 25 серпня. Доба гетьмана Івана Мазепи в документах / упоряд. С. Павленко. Київ : Вид. дім «КиєвоМогилян. акад.», 2007. С. 198-199.

3. Лист гетьмана I. Мазепи до московського патріарха Адріана, 1695 р., 9 березня. Доба гетьмана Івана Мазепи в документах / упоряд. С. Павленко. Київ : Вид. дім «Києво-Могилян. акад.», 2007. С. 185.

4. Лист гетьмана I. Мазепи до о. Михайла Лежайського, архімандрита Спаського монастиря в Новгороді-Сіверському, 1687 р. (не раніше серпня). Доба гетьмана Івана Мазепи в документах / упоряд. С. Павленко. Київ : Вид. дім «Києво-Могилян. акад.», 2007. С. 123-124.

5. Лист гетьмана I. Мазепи до патріарха московського Адріана, 1695 р., 8 лютого. Доба гетьмана Івана Мазепи в документах / упоряд. С. Павленко. Київ : Вид. дім «Києво-Могилян. акад.», 2007. С. 184.

6. Лист гетьмана I. Мазепи до чернігівського архієпископа Феодосія Углицького, 1695 р., 21 грудня. Доба гетьмана Івана Мазепи в документах / упоряд. С. Павленко. Київ : Вид. дім «КиєвоМогилян. акад.», 2007. С. 189.

7. Лист гетьмана I. Мазепи ігуменові Свято-Михайлівського монастиря Сильвестру Головчичу, 1693 р., 12 липня. Доба гетьмана Івана Мазепи в документах / упоряд. С. Павленко. Київ : Вид. дім «Києво-Могилян. акад.», 2007. С. 181-182.

8. Лист І. Мазепи до київського полковника К. Мокієвського про надання київському митрополиту Варлааму Ясинському на Софіївський кафедральний собор прибутків 3 «помірного пашенного» 3 товарів, що продаються на житньому торзі в Нижньому Києві, 1691 р., 4 січня. Доба гетьмана Івана Мазепи в документах / упоряд. С. Павленко. Київ : Вид. дім «Києво-Могилян. акад.», 2007. С. 156.

9. Лист-наказ гетьмана I. Мазепи менському сотникові Івану Курочці (Курському) провести розмежування між Максаківським монастирем і менськими жителями, 1687 р., 12 листопада. Доба гетьмана Івана Мазепи в документах / упоряд. С. Павленко. Київ : Вид. дім «Києво-Могилян. акад.», 2007. С. 127. 
10. Лист І. Мазепи до ігумена Свято-Микільського Крупицького монастиря в Батурині, 1697 р., 4 листопада. Доба гетьмана Івана Мазепи в документах / упоряд. С. Павленко. Київ : Вид. дім «Києво-Могилян. акад.», 2007. С. 196-197.

11. Мацьків Т. Гетьман Іван Мазепа в західноєвропейських джерелах 1687-1709 рр. Вид. 2-е, допов. Київ ; Полтава, 1995. URL: http://litopys.org.ua/coss4/mazk.htm (дата звернення: 01.11.2021).

12. Оглоблин О. Гетьман Іван Мазепа та його доба. Нью-Йорк ; Київ ; Львів ; Париж ; Торонто, 2001. URL: http://litopys.org.ua/coss3/ohl.htm (дата звернення: 01.11.2021).

13. Павленко С. Іван Мазепа. Київ : Вид. дім «Альтернативи», 2003. 315 с.

\section{References:}

1. Krupnyts'kyi, B. (2003) Het'man Mazepa ta yoho doba [online]. Kyiv. Available at: <https: //www.e-reading.club/bookreader.php/1014572/> [Accessed 01 November 2021]. [in Ukrainian].

2. Lyst het'mana I. Mazepy do kyivs'koho mytropolyta Varlaama Yasyns'koho. 1699 r., 25 serpnya. In: Pavlenko S., comp. (2007) Doba het'mana Ivana Mazepy v dokumentakh. Kyiv: Vydavnychyy dim «Kyievo-Mohylyans'ka akademiya», pp. 198-199. [in Ukrainian].

3. Lyst het'mana I. Mazepy do moskovs'koho patriarkha Adriana. 1695 r., 9 bereznya. In: Pavlenko S., comp. (2007) Doba het'mana Ivana Mazepy $v$ dokumentakh. Kyiv: Vydavnychyi dim «Kyievo-Mohylyans'ka akademiya», pp. 185. [in Ukrainian].

4. Lyst het'mana I. Mazepy do o. Mykhayla Lezhays'koho, arkhimandryta Spas'koho monastyrya v Novhorodi-Sivers'komu. 1687 r. In: Pavlenko S., comp. (2007) Doba het'mana Ivana Mazepy v dokumentakh. Kyiv: Vydavnychyi dim «Kyievo-Mohylyans'ka akademiya», pp. 123-124. [in Ukrainian].

5. Lyst het'mana I. Mazepy do patriarkha moskovs'koho Adriana. 1695 r., 8 lyutoho. In: Pavlenko S., comp. (2007) Doba het'mana Ivana Mazepy v dokumentakh. Kyiv: Vydavnychyi dim «Kyievo-Mohylyans'ka akademiya», pp. 184. [in Ukrainian].

6. Lyst het'mana I. Mazepy do chernihivs'koho arkhiyepyskopa Feodosiya Uhlyts'koho. 1695 r., 21 hrudnya. In: Pavlenko S., comp. (2007) Doba het'mana Ivana Mazepy v dokumentakh. Kyiv: Vydavnychyi dim «Kyievo-Mohylyans'ka akademiya», pp. 189. [in Ukrainian].

7. Lyst het'mana I. Mazepy ihumenovi Svyato-Mykhaylivs'koho monastyrya Syl'vestru Holovchychu. 1693 r., 12 lypnya. In: Pavlenko S., comp. (2007) Doba het'mana Ivana Mazepy v dokumentakh. Kyiv: Vydavnychyi dim «Kyievo-Mohylyans'ka akademiya», pp. 181-182. [in Ukrainian].

8. Lyst I. Mazepy do kyyivs'koho polkovnyka K. Mokiyevs'koho pro nadannya kyyivs'komu mytropolytu Varlaamu Yasyns'komu na Sofiyivs'kyy kafedral'nyy sobor prybutkiv z «pomirnoho pashennoho» z tovariv, shcho prodayut'sya na zhytn'omu torzi v Nyzhn'omu Kyyevi. 1691 r., 4 sichnya. In: Pavlenko S., comp. (2007) Doba het'mana Ivana Mazepy v dokumentakh. Kyiv: Vydavnychyi dim «Kyievo-Mohylyans'ka akademiya», pp. 156. [in Ukrainian].

9. Lyst-nakaz het'mana I. Mazepy mens'komu sotnykovi Ivanu Kurochtsi (Kurs'komu) provesty rozmezhuvannya mizh Maksakivs'kym monastyrem i mens'kymy zhytelyamy. 1687 r., 12 lystopada. In: Pavlenko S., comp. (2007) Doba het'mana Ivana Mazepy v dokumentakh. Kyiv: Vydavnychyi dim «Kyievo-Mohylyans'ka akademiya», pp. 127. [in Ukrainian].

10. Lyst I. Mazepy do ihumena Svyato-Mykil's'koho Krupyts'koho monastyrya v Baturyni. 1697 r., 4 lystopada. In: Pavlenko S., comp. (2007) Doba het'mana Ivana Mazepy v dokumentakh. Kyiv: Vydavnychyi dim «Kyievo-Mohylyans'ka akademiya», pp. 196-197. [in Ukrainian].

11.Mats'kiv, T. (1995) Het'man Ivan Mazepa $v$ zakhidnoievropeys'kykh dzherelakh 1687-1709 $r r$. [online]. 2nd ed. Kyiv; Poltava. Available at: <http://litopys.org.ua/coss4/mazk.htm> [Accessed 01 November 2021]. [in Ukrainian].

12. Ohloblyn O. (2001) Het'man Ivan Mazepa ta yoho doba [online]. New-York. Available at: http://litopys.org.ua/coss3/ohl.htm [Accessed 01 November 2021]. [in Ukrainian].

13. Pavlenko S. (2003) Ivan Mazepa. Kyiv: Vydavnychyi dim «Al'ternatyvy». [in Ukrainian]. 